\title{
Subjetividades corporalizadas: \\ "Maldito amor" de Rosario Ferré y \\ Jamás el fuego nunca de Diamela Eltit
}

\section{María Inés Lagos ${ }^{1}$}

\begin{abstract}
SÍNTESIS
Este ensayo examina el énfasis en la corporalidad en narraciones de dos escritoras hispanoamericanas, las novelas Maldito amor (1986) de Rosario Ferré y Jamás el fuego nunca (2007) de Diamela Eltit. A partir de teorías que consideran el cuerpo en su historicidad, la corporalidad como intrínseca al sujeto y la importancia de las relaciones intersubjetivas, este estudio propone que al subrayar la corporalidad del sujeto se alude a la intersección entre intimidad individual, relaciones con el otro y valores de las respectivas sociedades como elementos fundamentales en la construcción de la subjetividad. Mediante la representación de subjetividades corporalizadas estos textos revelan intimidades concretas y únicas en las que cobran especial relevancia las diferencias genéricas.
\end{abstract}

\begin{abstract}
This essay examines the emphasis on corporeality in narratives by two Spanish American writers, Rosario Ferré's "Maldito amor" (1986) and Diamela Eltit's Jamás el fuego nunca (2007). Using as a framework theories that consider the body as historical, corporeality as intrinsic to subjectivity, and the importance of intersubjective relations, this study proposes that in highlighting the subject's corporeality the texts allude to the intersection between individual intimacy, relations with the other, and society's values as foundations in the making of individual subjects. By representing subjectivity in their corporeality, these texts reveal concrete and unique intimacies in which gender acquires special relevance.
\end{abstract}

Palabras claves: Subjetividad - corporalidad - cuerpo - Ferré - Eltit.

Key words: Subjectivity - corporeality - body - gender - Ferré - Eltit.

Con frecuencia encontramos en los textos literarios referencias a la corporalidad. Los ejemplos abundan a lo largo de la 
historia en las literaturas de las culturas occidentales, como lo sugieren los símiles y metáforas en los sonetos renacentistas, las figuras de Don Quijote y Sancho, el personaje de Tristana en la novela de Galdós, la imponente presencia de don Fermín de Pas en La Regenta de Clarín, las caracterizaciones de Esteban Echeverría en "El matadero" o las poderosas imágenes del poema de César Vallejo "Los heraldos negros", para nombrar algunos ejemplos de la literatura escrita en castellano. Estas representaciones perduran en la memoria del lector y, como se observa en el poema de Vallejo, el lenguaje poético revela cómo un sujeto experimenta "golpes como del odio de Dios" que "abren zanjas / oscuras en el rostro más fiero y en el lomo más fuerte" evocando una subjetividad corporalizada en la que "todo lo vivido / se empoza... en la mirada."

En narraciones de escritoras hispanoamericanas contemporáneas encontramos un marcado énfasis en la corporalidad para representar la subjetividad. En este ensayo reflexionaré sobre dos novelas, "Maldito amor" (1986) de Rosario Ferré (Puerto Rico, 1942) y Jamás el fuego nunca (2007) de Diamela Eltit (Chile, 1949). En "Maldito amor" - novela corta que forma parte con otros tres relatos del volumen Maldito amor- las referencias a raza y género adquieren especial relevancia en el discurso de los hablantes, y en Jamás el fuego nunca la voz narrativa expresa su intimidad a través de continuas referencias al cuerpo y la enfermedad. Estos textos se distinguen por la presencia de voces de mujeres que interactúan con un entorno de valores establecidos y difícilmente modificables, especialmente en cuanto a consideraciones raciales y de género. Aunque en gran medida hoy se ha trascendido la barrera que menciona Hélène Cixous en su manifiesto de 1975, "La risa de la Medusa", cuando exhorta a las mujeres a escribirse -como antes lo había hecho Virginia Woolf en Un cuarto propio (1929) - sin ignorar el cuerpo, el énfasis en la corporalidad del sujeto en textos de escritoras hispanoamericanas nos lleva a preguntarnos cómo se la utiliza en la práctica narrativa y qué revela de las hablantes y su mundo.

Mientras la literatura parece haber establecido una relación fluida entre la materialidad del cuerpo y lo emocional y psíquico en la representación de la subjetividad, en la filosofía occidental predominó una concepción del sujeto basada en el dualismo cartesiano que supone "dos distintas, mutuamente exclusivas 
[...] sustancias, mente y cuerpo, [en las que] cada una habita su propia y autocontenida esfera" (Grosz, 1994, 6). ${ }^{2}$ Para los feminismos y las teorías de género, el psicoanálisis y las tendencias filosóficas contemporáneas han sido fundamentales al considerar el cuerpo como un producto psicosocial (Grosz, 1992, 39). Para Margaret Lock y Judith Farquhar, "larga ha sido la lucha de las ciencias humanas para restablecer la idea de que el cuerpo es algo más que un apéndice de la mente" (19). El cuerpo, entonces, "nunca es simplemente un objeto físico sino más bien [...] el sitio donde la intencionalidad, el sentido, y toda práctica se originan" (Lock y Farquhar, 6). En Volatile Bodies. Toward a Corporeal Feminism, siguiendo los principios señalados por Foucault sobre el carácter histórico del cuerpo, Elizabeth Grosz propone entender la relación cuerpo/mente considerando el modelo de la cinta de Moebio -idea que se inspira en una sugerencia de Lacan (Grosz, 1994, xii)- de modo que cuerpo y mente no se entienden como dos substancias distintas sino que, como las dos caras en la cinta de Moebio que retorciéndose se entrelazan, un lado se transforma en el otro (Grosz, 1994, xii). ${ }^{3}$ Esta concepción difiere de aquella que considera al cuerpo como un medio a través del cual se expresa la conciencia del sujeto, pues considera la corporalidad intrínseca al sujeto. ${ }^{4}$

Al examinar estas novelas me apoyaré también en el concepto de "circulación" social en los intercambios del sujeto con el otro que sugiere Kelly Oliver, según el cual, la subjetividad se va constituyendo en un "continuo proceso de intercambios intersubjetivos" (151). Oliver escribe que "el yo y el otro son ilusorios subproductos de la subjetividad, tal vez más aún, lo que queda del continuo proceso de intercambios intersubjetivos que alimentan y a veces amenazan" (151). Y agrega: "no podemos escaparnos de la circulación de nosotros mismos y de nuestras relaciones con los otros" (151).

Tanto en la novela de Ferré como en la de Eltit la corporalidad subraya la intersección entre la intimidad individual, las relaciones con el otro y los valores de las respectivas sociedades. En "Maldito amor" la comunidad atribuye a la apariencia física, especialmente en relación a la raza, modos de convivencia en la sociedad que no se manifiestan abiertamente sino de manera solapada, y en Jamás el fuego nunca la hablante reflexiona desde su situación personal en estrecha relación con otros, de manera 
que en ambos casos el sujeto se presenta en un entrecruzamiento entre lo individual y lo social, como bien lo indica el término célula, referido tanto a la unidad física como a un grupo político disidente. El discurso de la narradora en la novela de Eltit parece originarse en el mundo privado pero, igual que en "Maldito amor", se extiende al ámbito social en su continuo intercambio con el otro, ya se trate de la pareja de la mujer que habla o de los miembros de la célula clandestina para la que ha trabajado con tesón. Propongo leer aquí las narraciones de Ferré y Eltit a la luz de estos parámetros que ayudan a deslindar el modo como se retrata la subjetividad en ellas, una subjetividad corpórea constantemente entreverada por los estímulos y valoraciones del mundo externo.

En la novela de Ferré la corporalidad cobra especial relevancia en cuanto a la raza, categoría social que incide en el modo como el individuo es visto y cómo se ve a sí mismo. Es decir, la conciencia del propio cuerpo como objeto valorado o devaluado por la cultura, un hecho histórico y cultural, se relaciona con el sutil juego social que destaca, esconde o transforma la apariencia corporal, de manera que conforma no solo la construcción y fragmentación de la identidad nacional sino también de la subjetividad individual. De allí que la atención que se presta a la apariencia física se transforma en factor decisivo no solo para dilucidar la posición que los sujetos ocupan en el orden social sino en cómo se perciben a sí mismos. Por otra parte, en Jamás el fuego nunca la narradora evoca una situación de carácter terminal tanto a nivel individual como social, a partir de una subjetividad ya fuera del tiempo, de la que no es posible escapar; sin embargo, a pesar de su condición terminal y definitiva, al narrarse en el presente se postula como proceso y, como tal, abierta a posibles opciones. En ambas novelas la corporalidad alude a situaciones que van más allá de lo meramente individual, y la acción se sitúa en períodos de cambio, al final de una era que cierra un ciclo. En Maldito amor se produce un cambio drástico en el sistema económico y de producción cuando las centrales azucareras de Guamaní -lugar ficticio que representaría a Puerto Rico- pasan a manos de accionistas norteamericanos; y en Jamás el fuego nunca, la célula clandestina cesa de ser viable y está a punto de desmoronarse, hecho que coincide con el intento, aparentemente frustrado, de la narradora de dar a luz. 
El acento en la corporalidad para representar la subjetividad no es un tema nuevo en las narraciones de estas dos escritoras. Desde sus primeros cuentos, en Papeles de Pandora (1976), Ferré ha subrayado subjetividades corporalizadas en su representación literaria de personajes y voces femeninas. Por ejemplo, el cuento "Cuando las mujeres quieren a los hombres" puede considerarse una parodia de la distinción que la sociedad tradicional ha construido en base a la corporalidad de dos mujeres, una blanca y otra negra, la señora y la prostituta, sugiriendo que no son tan distintas una de la otra ya que ellas mismas se imitan y admiran secretamente, y a veces se funden y confunden. En otro cuento de la misma colección, "Amalia", una niña, comparada a una muñeca de cera, sufre de una enfermedad que le impide salir al sol, sin embargo cuando finalmente se escapa al patio no le pasa nada, al contrario, se siente libre y se salva de la destrucción que ocurre dentro de la casa, lo cual pone en duda la naturaleza de la enfermedad que la ha mantenido encerrada sin poder disfrutar del aire y el sol por miedo a deshacerse, como le sucede a la muñeca que se derrite. ${ }^{5}$ Asimismo, en Eltit encontramos voces y personajes enraizados en su corporalidad, tema recurrente en sus obras desde Lumpérica (1983) hasta su última novela. Recordemos la desafiante presencia de L. Iluminada, protagonista de Lumpérica, en la plaza que habita y donde permanece durante toda la noche como sujeto que transgrede las ordenanzas de las autoridades; la voz de la melliza en El cuarto mundo (1988), quien escribe, mientras gesta a la niña, la novela que leemos; y la voz del niño subnormal en Los vigilantes (1994), sujeto al que se presenta en su materialidad corporal reaccionando ante el mundo exterior y la conflictiva relación entre sus padres. ${ }^{6}$

La mirada desde el exterior, que se manifiesta en el juicio de la comunidad como creadora de valores sociales por un lado, y la mirada interna, que se entrecruza con esos valores, inciden en el modo como el individuo vive y evalúa su corporalidad. La mirada de quien juzga por la apariencia física, incluyendo no solo el color de la piel sino el modo de vestir, de gesticular y de moverse, ejerce un poder incalculable que impregna la opinión de quien observa cuando aquilata al otro en su identidad individual y social, proceso que muestra cómo funciona la cultura y cómo se establecen categorías que clasifican o discriminan. Así, el modo como racionalizamos lo que percibimos está empapado de 
valores culturales que someten al individuo a la mirada de aquel que juzga al considerar las manifestaciones corporales de manera culturizada; de igual manera, en el proceso de "circulación" social (Oliver), aspectos materiales y tangibles de la corporalidad o rutinas adquiridas son inseparables de la subjetividad.

El análisis de Frantz Fanon en Peau Noire, Masques Blancs (1952) resulta esclarecedor para leer "Maldito amor". Allí Fanon describe las complejas repercusiones del color de la piel en las sociedades coloniales del Caribe y postula que junto a la pigmentación también el género es un factor diferenciador en la conducta social de hombres y mujeres. Para el hombre negro la piel oscura es una marca de inferioridad que lo subordina, pero existe la posibilidad de escapar de esa subordinación si domina la lengua del hombre blanco y actúa culturalmente como blanco, habilidades y conductas que el colonial aprende cuando vive en la metrópolis. No obstante, pocos tienen acceso a este privilegio, ya sea por su carencia de educación o de medios económicos. Entre los privilegios que aporta la riqueza a los coloniales que pertenecen a las clases acomodadas se cuenta el hecho de que el color desaparece, se ignora. Para las mujeres, por otro lado, casarse con un hombre blanco o de piel más clara es parte del proceso de blanqueamiento al que aspiran muchas de ellas para ascender en la escala social. Este gesto de rechazo por parte de la mujer ante el hombre negro no solo subraya su sentimiento de inferioridad, sino que afecta también a la mujer, quien normalmente acaba subordinándose al hombre blanco para conseguir el propósito de pertenecer a su mundo. De allí que no es s0lo el hombre negro el que se subordina al mundo blanco sino también la mujer, aunque por distintas razones. A esto hay que agregar otras situaciones, por ejemplo la del hombre negro que quiere probar su poder y se presenta como un ser fuerte, orgulloso, y hasta avasallador. Tener en cuenta estas actitudes que crea la sociedad colonial puede ayudarnos a leer la estrategia social de escondite y soslayo de la apariencia física que se observa en "Maldito amor".

La apariencia física se carga de sentido en la novela de Ferré al convertirse en sitio de distinciones establecidas por la comunidad que influyen en la identidad individual. Hermenegildo Martínez, abogado, periodista y "apasionado novelista" (38) comienza su relato describiendo una sociedad paradisíaca que sirve de trasfondo al retrato del prócer Ubaldino de la Valle, cuya historia 
se propone contar. A la manera de un narrador decimonónico que mira desde arriba a sus personajes, Martínez parece aferrarse a una imagen que intenta inscribir en la página antes de que desaparezca, pues Guamaní ha pasado a formar parte del sistema económico de Norteamérica. El novelista se presenta como figura de autoridad, pero a medida que avanza su narración lo que prometía ser una apología del prócer y de una comunidad idílica da un vuelco cuando varios narradores interrumpen sus elogiosas descripciones y ofrecen otras versiones de la historia de la familia De la Valle, de manera que la imagen inicial se hace cada vez más ambigua y, por último, indescifrable. ${ }^{7}$

Hijo de Doña Elvira De la Valle, o Elvira de las cuatro D -“Del Roble, De la Cerda, De la Valle y De Juan Ponce de León” (11)- y de Don Julio Font, Ubaldino comparte, con las tías de su madre, obsesionadas por la pureza de sangre, la afición a leer libros de genealogía (65). Sobre su padre se decía que "había nacido en una aldea ganadera de Lérida, y su enorme cuello de toro, así como su pecho de fleje y empaque, tan distintos de los empalagosos refinamientos de sus pretendientes, le resultaban [a Elvira] muy atractivos" (12), que era "un español prestigioso, importador de aceite, granos y bacalao" (12) y varias veces se mencionan sus "ojos dorados" (12). Aunque inicialmente las tías se preocupan por los efectos del apasionado enamoramiento en la sobrina, no solo consienten al matrimonio de Elvira y Julio sino que celebran que un hombre trabajador se haga cargo de la central azucarera, propiedad de la familia y de cuyas ganancias dependen para mantener su posición social. No obstante, a pesar de su aprobación y de que Elvira se casa por amor, el lector advierte algo sospechoso en la relación pues a Elvira se la presenta como "la pobre Doña Elvira" (12). Si bien es cierto que después del casamiento Julio rescata la central azucarera del desastre financiero, tal como esperaban las tías, el marido se niega a proporcionarle a su mujer las comodidades a las que está acostumbrada, trata con dureza a los subordinados - práctica que desdice de las tradiciones familiares-, y acaba maltratando a Elvira. La aristocrática Elvira sufre en silencio la humillación a que la somete el esposo y muere poco después del nacimiento de su hijo Ubaldino, quien, educado por las tías, hereda su ilustre apellido.

La primera en interrumpir las descripciones del narrador es la antigua sirvienta de la casa e hija de una esclava liberta, 
Titina, quien introduce un estilo oral y preocupaciones cotidianas que contrastan con el discurso altisonante del novelista. Entre los miembros de la familia que presentan sus propias perspectivas se cuenta Laura, mujer de Ubaldino, su hijo Arístides y Gloria Camprubí. Esta última, "una mulata hermosa, de esas que detienen el tráfico" (43) según Arístides, estudia para enfermera cuando éste la conoce, pero cuando la trae a la casa, según se descubre más adelante, se opone a que se siente a Gloria a la mesa con la familia porque es negra (72); en cambio Laura la acoge y la emplea para que se haga cargo de su marido enfermo de sífilis. De amante de Arístides, Gloria termina casándose con su hermano Nicolás, se transforma en amiga y confidente de Laura, cuida a Ubaldino hasta su muerte y es la madre de Nicolasito. La relación de Gloria con los tres hombres de la familia revela no solamente la promiscuidad sexual en las familias de abolengo, sino que ésta agrega nueva información sobre Julio Font, ingrediente importante para establecer la genealogía de la familia y dejar al descubierto los valores de la sociedad guamaneña.

Las tres mujeres que desbaratan el relato de Hermenegildo -Titina, Laura y Gloria- trastruecan con sus revelaciones la leyenda fundacional que pretendía inmortalizar Hermenegildo. Aunque también Arístides juega un papel fundamental cuando le confiesa al novelista su versión de los secretos de la familia, son las tres mujeres las que con su intervención dejan en evidencia aquello que se ha ocultado para proteger, supuestamente, la reputación familiar.

La experiencia de Laura, a cuyo matrimonio con Ubaldino en un principio se oponen las tías, es muy diferente de la de Elvira. Consciente de su lugar en la sociedad por ser descendiente de inmigrantes corsos de escasos recursos y de padre mulato, Laura no podía aspirar a casarse con un hombre de la posición de Ubaldino, destacado hombre público y perteneciente a las antiguas familias terratenientes. Pero, como le confiesa a Hermenegildo, Laura logra convertirse en la mujer del prócer a pesar de provenir de un grupo marginal: después de recibir la herencia de su padre e invertirla en la central azucarera, consigue que se la respete. En su lecho de muerte, es cabeza de una familia de prestigio y antiguas raíces, cuyas hijas se han casado con hombres de la nueva clase dirigente. La gestión de Laura es clave en la representación de unos personajes cuya subjetividad está entrelazada 
con la situación de privilegio a la que han accedido gracias a la posición familiar. Laura se presenta ligada a sus orígenes y al modo como los otros la ven, pero no acepta pasivamente lo que hubiera sido su destino sino que interviene adoptando un papel activo al hacerse su vida. En su versión de la historia de la familia revela aspectos relacionados con la apariencia física que condicionan las relaciones intersubjetivas en su sociedad y que, a su vez, tienen implicaciones en la creación de su subjetividad. Como Titina y luego Gloria, Laura deja al descubierto lo que la narración de Hermenegildo ha omitido al construir con su discurso novelesco la historia del prócer que, según él, fue Ubaldino de la Valle. En el presente de la acción, mientras Laura está a las puertas de la muerte, su hijo Arístides y sus hijas, así como el narrador, Titina y Gloria, esperan la decisión de esta mujer que tiene el poder de disponer cómo se va a repartir la herencia. Sus hijos temen que nombre a Gloria y a su hijo Nicolasito -de paternidad incierta- herederos de la central azucarera, por lo que ya anticipan el despojo. La novela termina con el monólogo de Gloria, mujer que también comienza en un papel subordinado, como la hermosa "mulata" (43) -más tarde llamada "negra" (72) - que seduce a Arístides.

Las voces de las mujeres muestran cómo la clase dirigente ha contribuido a construir una comunidad en la cual sus ciudadanos han estado sujetos a un tipo de circulación social propugnada por los valores de un grupo que privilegia determinados rasgos físicos o ciertos orígenes. El discurso narrativo sugiere que estas narradoras son muestra de cómo la circulación social permite oportunidades en las relaciones intersubjetivas que influyen en la plasmación de subjetividades únicas, subjetividades que no pueden ignorar su corporalidad.

Aunque al terminar de leer la novela nos damos cuenta de que los descendientes de la familia De la Valle no son blancos, nadie menciona esto en un comienzo y los lectores no sospechamos que los orígenes del llamado Don Julio puedan constituir un problema. Al contrario, su procedencia metropolitana -se dice que es español- es signo de alcurnia en un país colonial. Resulta sorprendente, por lo tanto, que las tías de la elegante Doña Elvira, educada en Europa, que se dedican a leer los libros de genealogía, hayan aceptado a un pretendiente mulato como marido de su sobrina en una sociedad en que la piel oscura se considera un rasgo de inferioridad. 
En la serie de narraciones intercaladas, cuyas revelaciones echan por tierra la imagen ejemplar del prócer que Hermenegildo había intentado construir, quien verdaderamente desafía la versión del narrador es Laura. Por un lado su enfermedad desencadena el proceso que origina los testimonios de los otros narradores - Titina acude a la oficina de Hermenegildo para proteger la herencia que le había prometido su patrón, Ubaldino- y, por otro, el deterioro de su salud la lleva a reconocer su propia corporalidad. En sus entrevistas con Hermenegildo manifiesta tener conciencia de la relación entre su cuerpo y su identidad: a punto de morir, Laura se da cuenta de que es su cuerpo, que es una con su físico, pero no solamente ahora en su precariedad de enferma terminal sino que este sentimiento lo ha experimentado durante su vida, puesto que su propia genealogía - de la cual está muy consciente- ha marcado su posición en la familia y la sociedad. Moribunda pero lúcida, la viuda de Ubaldino lamenta que sus apellidos no hubieran sido suficientemente encumbrados para los De la Valle; sin embargo cuando contribuye a incrementar el patrimonio familiar este hecho se olvida, pues se respeta su dinero. Pero no ha sido ésta la única razón de su pesadumbre, sino el que sus hijas no se casaran dentro del medio que les hubiera correspondido por la alcurnia del apellido paterno (67). Cuando Laura descubre, por información que suministra Gloria, que la familia De la Valle había ocultado quién era en realidad Julio Font se da cuenta de la causa de la marginalización que sufrieron sus hijas. Gloria le dice a Laura que no entiende por qué a Julio Font le dicen Don Julio y se refieren a él como comerciante español cuando "ella lo había conocido y estaba segura de que no hablaba con acento extranjero" (68). Gloria lo sabe porque había frecuentado a los hijos de Font, sus vecinos. Ubaldino, en cambio, le había contado a su mujer que su padre era "un hombre muy bien parecido, de tez blanca como la nata y los ojos de un dorado profundo" (68), sin embargo, cuando Gloria oye esta descripción cree que Laura bromea: “Don Julio era en efecto, muy bien parecido - me dijo riendo- pero no era para nada como Ud. me lo acaba de pintar. Era un mulato alto y fornido, el mejor domador de caballos de toda la región" (68). Así descubre Laura que, a pesar de su educación, abolengo y viaje a Europa, Elvira "se había enamorado de un negro" (69) y que por esta razón a sus hijas las habían pasado por alto los galanes de Guamaní (69). 
Independentista y liberal en vida de su marido, Laura le había pedido a Ubaldino que les advirtiera a las tías "que no vuelvan a repetir frente a mí esas sandeces de quien es negro y quien no lo es" (66). Cuando le cuenta a Hermenegildo que el padre de Ubaldino "era negro" (69), comenta: "Aquí los aristócratas todo lo tapan, todos disimulan, todos se empolvan con la harina la respetabilidad o con el azúcar Polvo de Diamante" (69). Y agrega que tan mulato era su padre como los antepasados de toros, solo que a ella no le importa decirlo. A diferencia de sus hijas y de su hijo Arístides, Laura manifiesta que "si Gloria era negra ellos también lo eran porque su abuelo, Don Julio Font, era negro" (73). Laura es el único miembro de la familia De la Valle que reconoce la marginalización por el cuerpo y habla abiertamente sobre su identidad, mientras los demás ignoran u ocultan su genealogía. ${ }^{8}$ Además de ejercer un sentido de autodeterminación a través de su advertencia a las tías, de su posición política independentista y de sus revelaciones a Hermenegildo, que transforman la imagen de la familia, Laura decide quién recibirá la herencia de los De la Valle y así el futuro de la familia.

La conciencia, dentro del texto, de que la narración de Hermenegildo Martínez es discurso novelesco - para Gloria Hermenegildo es el "novelista más embustero de Guamaní" (79)muestra cómo un grupo social logra contar una historia parcial de sus orígenes en la que cuerpo y posición social contribuyen a crear la identidad nacional. El carácter metaficticio del texto permite también entrever cómo al mismo tiempo que Hermenegildo trata de construir su relato, las voces intercaladas deconstruyen la imagen unívoca creada por la clase terrateniente que hasta entonces había dominado la política y el discurso ocultando la realidad de los cuerpos. Pero si bien es cierto que a través de las varias voces llegamos a tener una imagen más amplia de la sociedad guamaneña, puesto que cada uno de los testigos añade una perspectiva diferente, es preciso reconocer que no llegamos a dilucidar quiénes son estos individuos cuya sexualidad y corporalidad se oculta o manipula.

A través de la historia de la familia De la Valle comprobamos que la apariencia física está sujeta a interpretaciones y lecturas, y que la corporalidad no solo ubica a la persona según categorías socialmente construidas sino que los individuos mismos y su grupo social alteran estos criterios. El color de la piel no parece 
afectar tanto a los hombres como a las mujeres, a Gloria, a Laura y a sus hijas, o por lo menos no se menciona en relación a Ubaldino y sus hijos. Si recordamos el análisis de Fanon, una multiplicidad de factores y circunstancias contribuyen a determinar la posición social en las sociedades coloniales, y entre estos la variante genérica puede afectar de manera diferente a los sujetos. En "Maldito amor", Julio actúa de manera prepotente frente a Elvira, afirmando así su capacidad de asimilarse a la clase hegemónica, en cambio Laura rechaza los prejuicios de las tías y expresa sus preferencias políticas a favor de la independencia de la isla, y cuando descubre quién era Julio Font adquiere plena conciencia del papel de los factores raciales en su propia familia.

Este texto, como otros de la autora, desenmascara los soportes ideológicos que ha utilizado la sociedad tradicional puertorriqueña para establecer distinciones sociales. José Luis González propone en "El país de cuatro pisos" que Puerto Rico es una especie de palimpsesto cultural y racial que se ha ido formando a través de la superposición de grupos migratorios a medida que se han ido afincando en el territorio nacional a lo largo de los siglos. Sus habitantes originales, los taínos, fueron exterminados durante el período de la conquista y luego reemplazados por los africanos que llegan como esclavos; a éstos se suman los grupos inmigrantes de origen europeo en el siglo XIX, entre los que se cuentan españoles, corsos y mallorquíes, entre otros. Así, el substrato básico no es indígena ni solamente español, sino que el componente africano es el fundamento de la nacionalidad. ${ }^{9}$ Este hecho, sugiere la novela, se ha escamoteado.

Si bien puede parecer difícil tergiversar la evidencia física corporal, la novela indica que la sociedad eurocéntrica ha leído los cuerpos de manera ideológica. Mientras Ubaldino llega a ser senador y ciudadano ejemplar, al padre de Laura, su suegro, se lo desprecia por ser mulato. Claramente el prestigio de Ubaldino le viene por la familia de su madre, mujer de la aristocracia azucarera de origen español y no por el lado de su padre. Cuando a la narración de Hermenegildo se agregan otras voces, cuando los testigos provienen de otros estratos, la historia se transforma en historias, pero no desaparecen las ambigüedades. Al contrario, los lectores nos damos cuenta de que al describir la historia nacional de Guamaní el narrador entrega imágenes teñidas culturalmente puesto que su versión representa un imaginario 
nacional de acuerdo a la idea que las clases dominantes han creado de sí mismas. Teniendo en cuenta cómo se han culturizado los cuerpos, la novela de Ferré ilumina el modo como una comunidad ha elaborado su narración nacional y cómo ésta incide en la subjetividad individual.

Rosario Ferré deshace y desecha los mitos nacionales. ${ }^{10} \mathrm{Al}$ concluir la novela es Gloria, la supuesta heredera de Laura, junto con su hijo Nicolasito, quien tiene la voz y acaba la narración que Hermenegildo comenzara como tributo a la genealogía del prócer. La muerte de Laura marca el fin de un modo de contar la historia de una familia, permitiendo la inclusión de otras voces y registros que hacen hincapié en que la versión que intentaba contar el narrador omnisciente para representar a toda la comunidad es en realidad solo una visión parcial, mientras el monólogo de Gloria termina la narración. En ese momento esta última se dispone a prender fuego a la casa y a la central azucarera entonando la canción que le da título al libro, Maldito amor. ${ }^{11} \mathrm{Su}$ acto sugiere que no hay más remedio que destruir esos libros de genealogías falsas y las obsesiones sobre las que se fundamenta la nación para comenzar otra vez. ${ }^{12}$ Pero si bien Gloria intenta acabar con el mundo del pasado precipitando el incendio y expresa su deseo de cambio alterando la letra de la canción que cantaba Elvira cuando se enamora de Julio Font, la canción -aunque modificada- se sigue cantando, lo cual indica que ni el fuego puede borrar completamente la historia y la cultura de generaciones.

En su prólogo a la segunda edición de Maldito amor, Ferré caracteriza su novela como "parodia de la novela de la tierra" (11), pero no hay que olvidar que en el contraste de perspectivas que establece el texto al pasar del discurso ampuloso de Hermenegildo Martínez a la cotidianeidad de los varios hablantes propone un modelo más inclusivo de la comunidad nacional. ${ }^{13}$ Si bien la intervención de Gloria y su decisión de quemar los vestigios del antiguo orden introducen la idea de borrón y cuenta nueva, la presunta heredera retoma, modificándola, la canción de Elvira, estableciendo así un quiebre con el pasado pero también una (inevitable) continuidad. Como sugería al comenzar estas reflexiones, conciencia y corporalidad, como las dos caras en la cinta de Moebio, se entrelazan, y estas subjetividades corporalizadas revelan modos únicos y cambiantes de estar en el mundo. ${ }^{14}$ 
La novela de Diamela Eltit, Jamás el fuego nunca, se abre con una escena donde dos individuos, en una cama, se acercan hasta calzar como dos piezas que se ensamblan.

Estamos echados en la cama, entregados a la legitimidad de un descanso que nos merecemos. Estamos, sí, echados en la noche, compartiendo. Siento tu cuerpo doblado contra mi espalda doblada. La curva es la forma que mejor nos acomoda porque podemos armonizar y deshacer nuestras diferencias. Mi estatura y la tuya, el peso, la distribución de los huesos, las bocas. La almohada sostiene equilibradamente nuestras cabezas, separa las respiraciones. (11)

Esta poderosa imagen inicial subraya la proximidad e interdependencia de una pareja como intimidades que armonizan en una postura que "deshac[e]" las diferencias, pero al mismo tiempo se observa el carácter único de cada uno cuando se menciona que las respiraciones no se confunden: "la almohada [...] separa las respiraciones". No obstante, luego nos damos cuenta de que lo que parece una escena en el presente, es la evocación de uno de los miembros de la pareja, de la mujer -"pienso ahora" (15), "me pregunto ahora" (20)- cuya historia trasciende el tiempo: con los huesos distribuidos, están "echados en la noche", "en el descanso que [se] merece[n]". ${ }^{15}$ En sus diálogos consigo misma, la narradora concibe su presencia en el mundo como dolor y recuerda obsesivamente algo que quedó incompleto.

Durante la mayor parte del relato la pareja está aislada, reducida a una cama en una pieza con cocina (166) que semeja una tumba ("la pared monolítica que nos cerca", 15), sin embargo desde un comienzo la narradora hace referencias a una célula clandestina a la que ambos, él y ella, pertenecen. Está claro que la célula, a punto de desmoronarse, no logrará sobrevivir si sus miembros continúan aislados por la falta de confianza entre ellos, pues no saben qué intenciones tiene cada uno o si son espías. La narradora solo encuentra solidaridad en una compañera de célula -a la que nombra, Ximena- que trata de ayudarla con los preparativos para el nacimiento de su bebé.

La relación más importante para la narradora es la que mantiene con su compañero y jefe de la célula. En el momento en que se sitúan sus evocaciones ambos viven de manera precaria con solo lo mínimo para subsistir, por lo que ella se ve obligada a 
racionar sus cigarrillos. Al comunicárselo, ya anticipa su respuesta, que manifestaría sin palabras, solo con gestos: “Tendré que decirte, mañana, sí, mañana mismo que habré de racionar tus cigarrillos, llevarlos al mínimo o definitivamente dejar de comprarlos. No nos alcanza. Apretarás las mandíbulas y cerrarás los ojos cuando me escuches y no me vas a contestar, lo sé" (11). Herido a consecuencia de una caída, él está tendido en la cama, prisionero de su cuerpo inmóvil, sobreviviendo gracias a la generosidad de la mujer que dedica gran parte de su tiempo a cuidarlo.

Aunque ella ha demostrado independencia e iniciativa propia como "avezada" (113) analista y luego es ella quien sale a la calle a cumplir con su trabajo de asear a unos ancianos, en su pesadilla recuerda que él es quien ejerce el poder y decide. Por ejemplo, la mujer cae en la tentación de desear un vestido que ha visto en una vitrina y el hombre se lo reprocha, según ella evoca el episodio: "No empieces con el tema del vestido, no lo hagas, no sigas, saca tus cuentas, entrégate a las cuentas, deja el vestido y la vitrina [...]" (113). Así, la mujer concibe su individualidad como parte de la pareja y de la célula. Irónicamente, la voz habla de sí misma, pero en realidad está siempre pensando en el otro, pendiente del otro que la limita, como si estuviera atada a una circulación social de la que no puede escapar. Como se observa en el episodio del vestido, la mujer desea el vestido y al mismo tiempo siente el veredicto del compañero que la inhibe, y no lo compra.

Con frecuencia aparece en sus pensamientos un niño de dos años al que la pareja no se atreve a llevar al hospital por miedo a que los reconozcan y los tomen prisioneros. El hijo, al igual que su proyecto político, no llega a materializarse, tal vez no alcanza a nacer. Ella teme que su pareja no le haya administrado correctamente el éter al no seguir con exactitud las instrucciones de Ximena pues sospecha que no quería que tuviera el bebé, pero como los recuerdos de ella son confusos no se sabe exactamente qué ocurrió, si el proyecto fracasa, si muere el bebé y también ella, o los dos a manos de él. Lo cierto es que la mujer continúa su relación con él a pesar de que parece responsabilizarlo de la muerte del niño, que resiente, y se presenta en un papel de subordinada, mentalmente dependiente del hombre.

Además de mantenerse en contacto con otros miembros de la célula, ella sale de la pieza para cumplir su horario de trabajo. 
Se relaciona brevemente con los cuidadores de los ancianos enfermos a los que les hace su aseo personal una vez por semana. La narradora es extremadamente ágil y eficiente, y ha desarrollado un sistema para dejarlos limpios y conseguir que le obedezcan. Hace su trabajo con lealtad, responsabilidad e integridad, pero no puede suplir el cuidado diario hecho con amor; los clientes solo reciben estos servicios por dinero. La mujer, que normalmente hurga en su conciencia, cuando asea a los ancianos es como una autómata, no se permite sentir sino solo cumplir sus funciones.

Un día tiene dificultades para llegar a su trabajo y, mientras espera en el autobús sin saber si bajarse o armarse de paciencia, examina sus reacciones: "Miro hacia adentro y hacia fuera. Me distrae la calle y me distrae el pasillo. En realidad, más allá de mis propios deseos, no puedo alejar mi mirada de la calle o del interior del bus, en una sucesión simétrica: la calle, el interior, como si fuera una vigía o una informante obligada a consignar" (147-148). En sus obsesivas reflexiones, la mujer se ve a sí misma inseparablemente unida a otros en relaciones intersubjetivas marcadas por necesidades de supervivencia. El tiempo, motivo importante de la novela como anticipan los adverbios del título, surge poderosamente en esta ocasión con su cualidad inexorable: "Siempre sentada en el interior de un bus lento, que no avanza, no avanza, esperando llegar a la hora. Una hora urgente que no debe sino ser desesperadamente exacta. Siempre" (157).

Si bien los episodios con los ancianos la sacan del encierro y le permiten recorrer la ciudad, estas visitas sirven de imagen especular de su propio encierro junto al compañero inmóvil, reiterando la atmósfera de decadencia física. Mientras los ancianos enclaustrados se deterioran visiblemente a pesar de sus esfuerzos, también la pareja y la célula parecen tener el mismo predecible final.

En sus evocaciones la narradora no se recuerda sola sino en relaciones de intercambio y dependencia con un círculo de personas, el compañero herido, los miembros de la célula, los ancianos clientes que visita cada semana y el niño por nacer o necesitado de cuidado médico. Este modo de narrar su yo subraya la intervención de las relaciones con los otros, de modo que, como sugiere Oliver a propósito de la circulación social, las relaciones intersubjetivas son parte de un proceso de intercambio 
que a veces nutre y otras amenaza al sujeto que no puede escapar de esa "circulación". "No podemos escapar de la circulación de nosotros mismos ni de nuestras relaciones con los otros. $Y$ en esta circulación, al mismo tiempo que nos movemos hacia los otros nos estamos retirando y recuperándonos para nosotros mismos", escribe Oliver (151-152).

En su monólogo, en forma de un continuo diálogo que sostiene consigo misma y con los otros, la narradora representa su mundo como algo tangible, con sus miserias, sentimientos, dolores, olores, es decir, a través de reminiscencias sensoriales. Se advierte un énfasis obsesivo en las funciones corporales (el hambre y la necesidad de alimentarse, la falta de control de sus excreciones en los ancianos), en la enfermedad (la tos de ella, el ahogo por el humo del cigarrillo que él insiste en fumar, el eczema de los viejos), los órganos sensoriales (con especial mención del ojo, la vista, el nervio óptico), y en la decrepitud que avanza inexorablemente (el eczema de los viejos y el deterioro de la vista de él, que ya no puede leer). La manifestación de las sensaciones corporales ocupa un lugar preeminente en la vida del compañero enfermo; además, con la reiterada presencia de cuerpos en declive el texto crea un ambiente de decadencia física sofocante, de desmoronamiento, de manera que la vida diaria es una lucha irremisible que no conduce a ninguna parte y no puede detenerse.

Así, la subjetividad corporalizada de la narradora aparece como el fundamento de su individualidad. Aquí resulta útil acudir a la antropología de la vida diaria -como "teoría de un espacio vivido" que se ha desarrollado en las últimas décadas (Lock y Farquhar, 241-243)- para iluminar las reminiscencias de la narradora cuando observa la vida de la ciudad desde el autobús. Pensemos en el paralelo que establece Michel de Certeau al comparar la experiencia de mirar la ciudad de Nueva York desde las torres gemelas con la vista que se tiene desde las calles. Mientras desde la calle se ve la ciudad vivida, desde arriba la impresión es considerablemente diferente (de Certeau, 91-94). En el episodio del autobús, el carácter corporal de la ansiedad que experimenta la mujer constituye un buen ejemplo de cómo la afecta el espacio en que se encuentra y desde el que describe sus sensaciones, sin separar sus reacciones emocionales de la aguda conciencia de su cuerpo. Por una parte se subraya el carácter repetitivo de las 
acciones, de la rutina diaria de recorrer la ciudad y, por otra, no se prescinde de lo inesperado, ${ }^{16}$ lo cual acentúa el carácter individual de la experiencia.

Jamás el fuego nunca explora la representación del cuerpo enfermo en estado terminal y la creación de una voz que obsesivamente está en contacto con su corporalidad. En cuanto al primer aspecto, no hay nada que nos acerque más a la percepción de que somos nuestro cuerpo que la enfermedad, que nos vuelve vulnerables y conscientes de que no podemos funcionar separadamente del cuerpo, y de que nuestra experiencia es intransferible, completamente individual. Esta es la situación por la que están pasando los personajes, quienes sienten las limitaciones en el uso del cuerpo - los efectos de una caída y el avance de la vejez-que les afecta de modo singular. La narradora pone de relieve que el dolor es sinónimo de estar vivo:

Me duelen, me duelen, dices o dejas de decir, y me alegra que todavía te duelan los huesos, que los sientas y se hagan presentes cada día o cada noche, cada hora, en todos los minutos, porque tú prácticamente no te levantas de la cama, de mi cama, y entiendes, tienes que hacerlo, que únicamente estás vivo por el poder de tus huesos que alardean su dolor, este engranaje tan consistente que tenemos y somos huesos, esqueleto puro, ¿no crees? (113, mi énfasis)

En situaciones normales ocurre lo opuesto: al respirar, movernos, comer y digerir, damos al cuerpo por sentado, pero cuando algo nos incomoda inesperadamente cobramos conciencia de estas funciones. En Lost Bodies, Laura Tanner señala que los cuerpos enfermos y el dolor están ausentes del discurso crítico y fuera de las visiones culturales. Las fuerzas sociales nos empujan hacia los cuerpos sanos y los cuerpos enfermos, especialmente en estado terminal, quedan desplazados (2). Ciertamente no es fácil leer el obsesivo relato de la narradora de Jamás el fuego nunca, quien, encerrada en un espacio reducido, sobre la superficie de una cama que más bien parece una tumba, recuerda que el mundo que con esfuerzo ha tratado de construir se derrumba. Además, su trabajo la lleva a compartir otras situaciones de desmoronamiento cuando asiste a los ancianos enfermos con su aseo. Si bien es cierto que esta actividad le permite dejar el cuarto varias veces a la semana, los enfermos no son siempre 
dóciles sino que a veces se ponen agresivos. En su trabajo la mujer aparenta no mostrar sus emociones al moverse con precisión y eficiencia, pero al leer sus reminiscencias nos damos cuenta de que está profundamente involucrada con lo que hace. Se trata de un tipo de relación intersubjetiva que la afecta emocionalmente, pues recuerda vívidamente esos episodios.

En segundo lugar, la sostenida introspección de la voz femenina le permite relatar sus experiencias desde sus sentimientos más profundos como si no hubiera distancia entre sus evocaciones y lo que siente en su cuerpo. Si bien el discurso novelístico no sustituye la experiencia de vivir cuerpos que se desmoronan, sí contribuye a evocarla.

Como en "Maldito amor", la historia que verbaliza la narradora parece, al terminar, más ambigua que al comienzo: no sabemos si lo que cuenta la mujer son recuerdos o delirios de su imaginación, ni estamos seguros si ha muerto de un golpe que le asesta su pareja, ni qué pasa con el bebé o cuál es el papel de cada uno de los miembros de la célula, quienes pueden haber querido salvarla o contribuido a su muerte. Tampoco sabemos si su narración corresponde a algo que le sucedió, pero lo cierto es que tenemos las reacciones de una narradora que siente, o dice que siente, y cuya conciencia expresa sus vivencias como una subjetividad que está en permanente contacto con su cuerpo. En su texto se mencionan reiteradamente partes del cuerpo asociadas a sus sensaciones y sentimientos a flor de piel, como zonas de contacto entre ella y el mundo.

A lo largo de su discurso la narradora manifiesta una obsesión por el futuro cuando nombra al niño, la esperanza fallida que no olvida. Aquí vale la pena recordar el poema de Vallejo "Los nueve monstruos", de Poemas humanos, uno de cuyos versos le da título a la novela: "jamás el fuego nunca / jugó mejor su rol de frío muerto!” (42). Como en el poema de Vallejo, el dolor de la narradora es continuo, sin pausa, y su monólogo insiste en el sufrimiento.

El poema comienza expresando desesperanza ("I, desgraciadamente, / el dolor crece en el mundo a cada rato" $)^{17}$ y repite el tema insistentemente, pero permite un atisbo de futuro en dos instancias, cuando dice "hay algunos / que nacen, otros crecen, otros mueren, / y otros que nacen y no mueren" (43), y al final hay un llamado al ministro de salud para concluir que "hay, 
hermanos, muchísimo que hacer" (44). Aunque la esperanza parece remota, como la porfía de la mujer que recuerda al niño, el poema indica con el último verso que el ser humano no se da por vencido fácilmente, ni aun en sus pesadillas. Si bien es cierto que no logra alcanzar el fuego -el fuego de la pasión, del amor, de la vida- en la última línea de la novela la mujer, posiblemente muerta, todavía mantiene su obsesión por el niño. Quiere salir a la calle y llevarlo al hospital, como si pudiera volver a vivir, rehacer el pasado:

Miro el montón de células que ya están en un avanzado deterioro, me detengo en tus células tiñosas y me dan ganas infinitas de decirte: levántate, o decirte: resucita de una vez por todas y salgamos a la calle con el niño, el mío, el de dos años, mi amado niño y llevémoslo al hospital. Debemos llevarlo porque, después de todo, ya no tenemos nada que perder. (166)

No obstante, esta oportunidad no se presenta pues el tiempo está estancado, solo existe en la conciencia de la mujer, más allá del tiempo. Como sugiere la duplicación de los adverbios de tiempo en el título, "jamás [...] nunca", el fuego de la pasión amorosa que da vida y la pasión por cumplir la tarea política no se materializan.

Para concluir, en las dos novelas la subjetividad se vive de modos diferentes y no solo por las diferencias históricas, geográficas y culturales, sino porque se trata de experiencias únicas, individuales, vividas en un tiempo y un lugar acotados. Si recordamos las palabras de Cixous a las que aludía al comienzo: "La mujer debe escribirse a sí misma: debe escribir sobre las mujeres y traerlas a la escritura, de la cual han sido apartadas tan violentamente como de sus cuerpos - por las mismas razones, por la misma ley, con el mismo propósito fatal-. La mujer debe ponerse en el texto, como en el mundo y en la historia por su propio movimiento" (245), ${ }^{18}$ y consideramos la propuesta de Margaret Lock cuando se refiere a sus investigaciones sobre el cuerpo en la cultura japonesa: "Ahora, más que nunca antes, es crucial poner seria atención al cuerpo vivido en su infinita variedad" (14), podemos inferir que al incorporar voces de mujeres que no ignoran su corporalidad y su entorno, Ferré y Eltit contribuyen a llamar la atención sobre la variedad de experiencias y a pensar la subjetividad sin eludir su carácter histórico y cultural, ni su 
intrínseca corporalidad. El modo como Rosario Ferré y Diamela Eltit escriben voces de mujeres en estos textos entrega versiones, desde perspectivas marginales, de cómo se construyen los mitos sociales a partir de la familia y de sus relaciones con el grupo social, pero, sobre todo, sus narraciones nos trasladan a mundos vividos como subjetividades corporalizadas, concretas y únicas.

\section{Notas}

1 Doctora en literaturas hispánicas en Columbia University, Nueva York. Actualmente es profesora de literatura latinoamericana y directora del Departamento de Español, Italiano y portugués de la Universidad de Virginia, EE.UU.

2 Las traducciones a lo largo del trabajo son mías.

3 Grosz afirma: "Bodies and minds are not two distinct substances or two kinds of attributes of a single substance but somewhere in between these two alternatives. The Moebius strip has the advantage of showing the inflection of mind into body and body into mind, the ways in which, through a kind of twisting or inversion, one side becomes another" (xii).

4 Esta concepción ha sido confirmada por estudios recientes sobre el cerebro. En la actualidad los estudios sobre la corporalidad han cobrado renovado interés en las diversas disciplinas; científicos, cientistas sociales y estudiosos de las ciencias humanas examinan las relaciones entre genética y conducta, entre cerebro y género, llegando a la conclusión de que aunque los factores biológicos (genes y hormonas) son fundamentales, las relaciones intersubjetivas y el medio ambiente están inextricablemente unidos a la realidad física. De allí que la oposición naturaleza/cultura, como sugiere Louann Brizendine (26), haya quedado obsoleta. Una buena síntesis de las nuevas tendencias en los estudios sociológicos actuales que tiene en cuenta las investigaciones genéticas y sociológicas se encuentra en "The Nature-Nurture Debate, Redux" de Christopher Shea, The Chronicle Review, 54, 31 (Enero 9, 2009).

5 Otro ejemplo es "La muñeca menor," cuento de Ferré frecuentemente incluido en antologías. Ver "Signos conflictivos del cuerpo en 'La muñeca menor' de Rosario Ferré". Lagos, María Inés. Hechura y confección. Santiago: Editorial Cuarto Propio. 2009, 167-187.

6 Sobre subjetividad y cuerpo en Eltit ver mi ensayo "Cuerpo y subjetividad."

7 Sobre la autoridad narrativa en "Maldito amor" véase María José Bustos Fernández. 
8 Harris comenta sobre el modo como los distintos personajes utilizan la terminología racial (46).

9 Sobre el carácter afro-antillano de Puerto Rico ver González, 20-22.

10 Ricardo Gutiérrez Mouat trata el tema de la relación entre "Maldito amor" y la historia nacional puertorriqueña.

11 Rosario Ferré señala en una nota a su traducción de la novela que el autor de la canción "Maldito amor", Juan Morel Campos, es mulato (Emmanuel Harris 35). La canción dice así: "Ya tu amor / es un pájaro sin voz / ya tu amor / se perdió en mi corazón / no sé por qué / me marchita tu pasión / y por qué no ardió" (13). La versión de Gloria al final de la novela dice: "ya tu amor / es un pájaro con voz / ya tu amor / anidó en mi corazón / ya sé por qué / me consume esta pasión / y por qué ardió" (79).

12 Julio Rodríguez-Luis se refiere a la frecuencia de los desenlaces trágicos y la destrucción causada por "piras incendiarias" en varios relatos de Ferré (587-593). Sin embargo, en cuanto a los incendios habría que considerar la práctica de estos actos como manifestaciones de protesta por parte de grupos subyugados a lo largo de la historia de la región. Algunos ejemplos del arte y la literatura se encuentran en la película La última cena (1976) de Tomás Gutiérrez Alea -que se refiere a un episodio del siglo XVIII en Cuba- y la novela Balún-Canán (1957) de Rosario Castellanos.

13 En una segunda edición de la novela la autora incluye un prólogo que titula "Memorias de Maldito amor", donde considera a "Maldito amor" una parodia de la novela de la tierra (11-12).

14 Para la perspectiva de una escritora sobre el mundo del Caribe y la transculturación, véanse los ensayos de Nancy Morejón, Fundación de la imagen (1988), en los que lee el mundo del Caribe desde el concepto de transculturación de Fernando Ortiz.

15 Sobre los ecos de Rulfo en esta novela, ver mi entrevista con la autora (111-112).

16 En esta formulación sigo un comentario de Michael Taussig (259).

17 Sigo aquí la ortografía de Vallejo.

18 Mi traducción de la versión al inglés de Keith Cohen y Paula Cohen, publicada originalmente en Signs 1, 4 (1976): 875-893; cito a Cixous de New French Feminisms, eds. Elaine Marks e Isabelle de Courtivron.

\section{Bibliografía}

Brinzendine, Louann. The Female Brain. New York: Broadway Books, 2006.

Bustos Fernández, María José. “Subversión de la autoridad narrativa en Maldito amor de Rosario Ferré". Chasqui (1994): 22-29. 
De Certeau, Michel. The Practice of Everyday Life. Trad. Steven Rendall. Berkeley: U California P, 1984.

Eltit, Diamela. Jamás el fuego nunca. Santiago: Seix Barral, Planeta, 2007. Fanon, Frantz. 1952. Black Skin, White Masks. Traducción del francés por Charles Lam Markmann. New York: Grove Weidenfeld, 1967.

Ferré, Rosario. Papeles de Pandora. México: Joaquín Mortiz, 1979.

----- Maldito amor. México: Joaquín Mortiz, 1986.

----- "Memorias de Maldito amor". Maldito amor. Buenos Aires: Sudamericana, 1992.

Foucault, Michel. The History of Sexuality, Vol I: An Introduction. Trad. Robert Hurley. Nueva York: Vintage, 1980.

González, José Luis. El país de cuatro pisos y otros ensayos. Río Piedras: Huracán, 1980.

Grosz, Elizabeth. "The Body". Feminism and Psychoanalysis. A Critical Dictionary. Ed. Elizabeth Wright. Oxford: Blackwell, 1992. 35-40. Volatile Bodies. Toward a Corporeal Feminism. Bloomington: Indiana UP, 1994.

Gutiérrez Mouat, Ricardo. “La 'loca del desván' y otros intertextos de Maldito amor". Modern Language Notes 109 (1994): 283-306.

Harris, Emmanuel Dwight. "Coloring Between the Lines: Racial Construction in Selected Works of Contemporary Caribbean Fiction." Doctoral Dissertation, Washington University in St. Louis, May 1998.

Lagos, María Inés. "Cuerpo y subjetividad en narraciones de Andrea Maturana, Ana María del Río y Diamela Eltit." Revista Chilena de Literatura, No. 50 (1997): 97-109.

------ “Conversación con Diamela Eltit a propósito de Jamás el fuego nunca." Hofstra Hispanic Review, 2, 5 (2007): 109-116.

----- Hechura y confección: Escritura y subjetividad en narraciones de escritoras latinoamericanas. Santiago: Cuarto Propio, 2009.

Lock, Margaret y Judith Farquhar, eds. "Introduction." Beyond the Body Proper. Reading the Anthropology of Material Life. Durham: Duke UP, 2007.

Morejón, Nancy. Fundación de la imagen. La Habana: Editorial Letras Cubanas, 1988.

Oliver, Kelly. Subjectivity without Subjects. FromAbject Fathers to Desiring Mothers. New York \& Oxford: Rowman and Littlefield Publishers, 1998.

Rodríguez-Luis, Julio. “De Puerto Rico a Nueva York: protagonistas femeninas en busca de un espacio propio." La Torre (NE) 7, 27-28 (1993): 577-594.

Shea, Christopher. "The Nature-Nurture Debate, Redux." The Chronicle Review, 54, 31 (January 9, 2009).

Tanner, Laura E. Lost Bodies. Inhabiting the Borders of Life and Death. Ithaca: Cornell UP, 2006. 
Taussig, Michael. "Tactility and Distraction." Lock, Margaret y Judith Farquhar, eds. Beyond the Body Proper. Reading the Anthropology of Material Life. Durham: Duke UP, 2007. 259-65.

Vallejo, César. Los heraldos negros. 1918. Lima: Perú Nuevo, 1961. Poemas humanos y España aparta de míeste cáliz. 1939. New York: Las Americas Publishing Co., 1965. 